Research Article

\title{
Producer Services Openness and the Development of Servitization: The Perspective of Two-Way Openness
}

\author{
Wei Chen, ${ }^{1,2}$ Yinzhong Chen $\mathbb{D}^{\mathrm{D}},{ }^{3}$ Yifei Hao, ${ }^{1,2}$ and Sili Chen ${ }^{1}$ \\ ${ }^{1}$ School of Business Administration, Chongqing Technology and Business University, Chongqing 400067, China \\ ${ }^{2}$ Research Center for Enterprise Management, Chongqing Technology and Business University, Chongqing 400067, China \\ ${ }^{3}$ Research Center for International Business and Economy, Sichuan International Studies University, Chongqing 400031, China
}

Correspondence should be addressed to Yinzhong Chen; chen-yinzhong@sisu.edu.cn

Received 13 August 2021; Revised 27 August 2021; Accepted 30 August 2021; Published 8 September 2021

Academic Editor: Daqing Gong

Copyright (C) 2021 Wei Chen et al. This is an open access article distributed under the Creative Commons Attribution License, which permits unrestricted use, distribution, and reproduction in any medium, provided the original work is properly cited.

This paper brings producer services "bringing in" and "going out" into the same analytical framework and explains the influence mechanism of producer services opening on the development of servitization from three aspects of import trade, FDI, and OFDI. On this basis, using the latest input-output data of WIOD, this paper constructs some indicators to measure the openness of producer services such as import trade penetration, FDI penetration, and OFDI penetration and then empirically tests the impact of producer services openness on the development of servitization in China. The results show that the openness of producer services has a significant positive impact on the development of China's servitization. In addition, the robustness analysis based on variable substitution and different estimation methods shows that the conclusions are robust. The heterogeneity test shows that the impact of producer services openness on servitization has heterogeneity. The specific performance is as follows: there is different impact of producer service sector openness on the development of servitization; the impact of producer service openness on the development of servitization with different factor intensities is also different; and there is also different impact of producer service sector openness on the development of servitization with different factor intensities. The policy implications of these research conclusions are as follows: firstly, taking co-construction of the "Belt and Road" as a chance to promote the new open pattern; secondly, focusing on expanding the openness of high-end producer services; and thirdly, taking innovation driven development as the guide to increase R\&D investment of producer services.

\section{Introduction}

Since the reform and opening up, relying on the comparative advantage of the production factors endowment, China has successfully embedded into the middle- and low-end links of the global production division network, which has promoted the rapid development of China's manufacturing industry. However, with the rising cost of production factors and the increasingly prominent problems of resources and environment, the traditional competitive advantage of China's manufacturing industry is weakening. Changing the mode of development and getting rid of the low-end lock of value creation has become an important issue for China's manufacturing industry to achieve high-quality development. In addition, in the context of global economic development moving forward to service economy, servitization is not only the main development trend of manufacturing industry but also an important measure for developed countries to compete for commanding the height of value creation. Therefore, in order to comply with the new development trend of global manufacturing industry, promoting the development of servitization has become an important means for China's manufacturing industry to achieve high quality.

Under the guidance of the report of the 19th National Congress of the Communist Party of China putting forward the idea of "bringing in" and "going out" with equal emphasis on opening up, the openness of China's service industry has ushered in a new opportunity. As an important part of the service industry, producer services are the core of 
expanding openness of service industry. Previous studies have shown that the openness of producer services helps to promote the development of servitization [1-3]. So, under the new pattern of expanding openness of productive services, how does the openness of productive services affect the development of servitization? Is there heterogeneity that the openness of different producer service sector influencing the development of servitization? Obviously, through in-depth discussion of these issues, it is a great practical significance to better understand and promote the openness of producer services and accelerate the development of servitization.

Based on the fact that the development and continuous expansion openness of global service industry, scholars have carried out a lot of research on the impact of service industry openness on economic development and formed fruitful research results. The main research topics related to this paper are as follows:

(1) Focusing on service trade, service industry FDI, and OFDI, scholars empirically analyzed the impact of producer services openness on manufacturing productivity from single or multiple aspects. The results showed that producer service import $[4,5]$, service trade liberalization [6-8], producer services FDI $[9,10]$, and OFDI $[11,12]$ have a significant impact on manufacturing productivity, and there was industry heterogeneity. At the same time, Fernandes and Paunov [9] pointed out that in producer services, FDI also provides opportunities for backward manufacturing enterprises to catch up. Li et al. [13] believed that the openness of producer services was an important way to improve the production efficiency of manufacturing enterprises. Chen et al. $[14,15]$ put producer services "bringing in" and "going out" into the same theoretical framework and examined the impact of two-way direct investment and openness of producer services on China's manufacturing productivity. In addition to empirical research, Kugler and Verhoogen [16], Fan et al. [17], and other researchers also analyzed the internal mechanism of service trade liberalization to improve the productivity of manufacturing enterprises from the theoretical aspect.

(2) Servitization is an inevitable development trend of manufacturing. It is an important path for the transformation and upgrading of manufacturing industry to promote the deep integration of producer services and manufacturing industry so as to realize the development of servitization. The openness of producer services can effectively improve the supply conditions and quality of intermediate producer service input factor, so it could promote the development of servitization [3]. Therefore, the impact of producer services openness on the development of servitization has also attracted scholars' attention. Yang [2] used the noncompetitive input-output model to examine the impact of producer service import on the development of servitization in OECD countries. Diao and Zhu [18] analyzed the impact of producer service import on the development of China's servitization from two aspects of "quality" and "quantity" and further investigated the heterogeneity impact of producer services on China's servitization. Zou et al. [3] put service industry openness and servitization into the same analysis framework and pointed out that service industry openness was conducive to improving the development of servitization. The influence of different service sector openness on the development of servitization was different.

In a word, the literatures generally believed that the producer services openness can improve the production efficiency and promote the development of servitization. Although the research on the impact of producer services on the development of servitization from the perspective of openness has increasingly aroused widespread concern in the academic community, there is still a lack of research on the issue of "bringing in" and "going out" of producer services under the same framework. Therefore, the possible marginal contribution of this paper lies in the following: put producer services "bringing in" and "going out" into the same analytical framework. Based on this, firstly, this paper theoretically explains the impact mechanism of producer services openness on the development of servitization; secondly, empirical study is carried out on the impact of producer services openness on the development of China's servitization from the overall and sector levels.

\section{Theory and Hypotheses}

The openness of producer services includes "bringing in" and "going out." Therefore, the following section will analyze the mechanism of the impact of productive service openness on the development of servitization from three aspects:

(1) The Impact Mechanism of Producer Service Import on the Development of Servitization. The import of producer service can increase the supply quantity and types of domestic producer service factor so as to improve the supply environment. The impact mechanism is as follows. Firstly, it intensifies the competition of domestic productive service factor market and then improves the supply quality of productive service factor. Shen and Liu [19] pointed out that service import can improve the mismatch of domestic resources, promote fair competition in the market, and play the role of survival of the fittest mechanism. Therefore, after entering the domestic market, the import producer service factor with obvious comparative advantages will form direct competition with the domestic producer service factor providers, forcing the domestic enterprises with lower production efficiency to gradually withdraw from the market and making more resources allocated to the more efficient producer service providers, thus improving the mismatch of domestic production resources. At the same time, in order to cope with the competitive impact of producer service 
import, domestic producer service providers should learn from foreign advanced management and operation mode and increase $R \& D$ investment and other measures to improve the supply quality and competitiveness. Secondly, it is to reduce the input cost of producer service factor in manufacturing industry and promote the development of servitization. Zhang et al. [7] pointed out that the producer service import could reduce the input cost of service factor so as to encourage manufacturing enterprises to peel off relevant service departments through service outsourcing behavior and increase the input of service factor through the complementarities and then promote the development of servitization. Thirdly, industry association is used to improve the servitization. Comparing with other input factors, producer service belongs to the intermediate input factors with higher knowledge and technology. Import producer service factor transfers the knowledge and technology contained in them to product by manufacturing process through the industry association, which not only improves the efficiency of manufacturing industry but also increases the service content of products, Fourthly, manufacturing enterprises are encouraged to increase $\mathrm{R} \& \mathrm{D}$ investment, and value creation is promoted to $R \& D$ and design. As an intermediate input factor, import producer services are put into the manufacturing process. Through the spillover effect of technology, experience, and knowledge, manufacturing enterprises are encouraged to increase $\mathrm{R} \& \mathrm{D}$ investment so as to improve the $\mathrm{R} \& \mathrm{D}$ and innovation ability, and the value creation gradually turns to R\&D and design [20-22]. So, it can be concluded that the import producer service improves the quality of domestic producer service through the competitive effect of producer service market and industrial connection and then promotes the development of servitization.

(2) The Impact Mechanism of Producer Services FDI on the Development of Servitization. Producer services FDI is an important factor to the development of servitization [3], and the specific impact is as follows. Firstly, it is the effect of technology transfer. Multinational producer service providers set up the oversea enterprises by the form of FDI, and the oversea enterprises not only forms forward-backward relationship with domestic suppliers and customers but also forms a horizontal relationship with the same type of domestic enterprises. Through the competition and cooperation with domestic enterprises, the proprietary technology, management experience, and marketing strategies brought by multinational enterprises are gradually transferred to domestic enterprises, which improves the supply quality and types of domestic service factor and reduces the input cost of service [9], thus promoting the development of servitization.
Secondly, it is the technology diffusion effect. Human capital flow, training, and learning are the main channels of producer services FDI technology diffusion. The human capital flow between multinational enterprises and domestic enterprises will spread and share the advanced technology, management experience, and knowledge accumulation from multinational enterprises to domestic enterprises, enhance the human capital of domestic producer service enterprises, promote the development of domestic producer service enterprises, and improve the supply quality of domestic producer service factor. Due to the exemplary of multinational producer service enterprises, domestic enterprises are inspired to learn, absorb, imitate, and even selfinnovate their service culture, management mode, and marketing strategy. In addition, in order to better adapt to the domestic market and achieve the purpose of providing localized service factor, multinational producer service enterprises need to train their domestic labor force and improve the human capital of domestic employees, and then through the way of personnel flow, the supply quality of human capital is promoted [3]. So, it can be concluded that producer services FDI transfers and spreads the advanced technology and management experience of multinational producer service enterprises to domestic enterprises through technology transfer and spillover effect, improves the supply environment of domestic producer service factor, and further promotes the development of servitization.

(3) The Impact Mechanism of Producer Services OFDI on the Development of Servitization. OFDI is an important way for domestic enterprises to "go out." Producer services OFDI mainly affects the development of servitization through reverse technology spillover channel. Through OFDI, domestic producer service enterprises can effectively embed into the local technology network to acquire and learn the local advanced technology and knowledge or use the local factor endowment to achieve technological progress and innovation. Then, the transfer of advanced technology to domestic enterprises is realized through personnel, information flow, and other channels. Therefore, different from the horizontal or vertical technology spillovers of FDI, the main channels for OFDI to affect the development of domestic producer services are R\&D cost sharing, peripheral $R \& D$ stripping, and $R \& D$ achievements feedback and transfer [23-25]. Through the reverse technology spillover of producer services OFDI, the input quality of domestic producer service factor is improved so as to promote the development of servitization. The specific impact is as follows. Firstly, it is the R\&D cost sharing. Producer service enterprises make full use of local factor endowment with comparative cost advantage to carry out noncore technology R\&D so as to reduce the R\&D cost. With 
the total R\&D cost unchanged, domestic producer service enterprises can allocate more funds on core technology $\mathrm{R} \& \mathrm{D}$, which improves the $\mathrm{R} \& \mathrm{D}$ innovation ability of domestic enterprises. Secondly, it is the separation of peripheral R\&D. Enterprises spin off noncore technology R\&D to foreign subsidiaries through OFDI so as to ensure that domestic enterprises can focus on core technology or new technology R\&D so that enterprises can keep ahead in technology for a long time. Thirdly, it is the feedback and transfer of $\mathrm{R} \& \mathrm{D}$ achievements. Through OFDI, producer service enterprises can make full use of local factor endowments, achieve technological progress and innovation in the local area by acquiring and learning local advanced technology and knowledge, or successfully embed local technology network through cooperation with local enterprises so as to master the cutting-edge technology and development trend and feed or transfer back to domestic. So, it can be concluded that the reverse technology spillover of OFDI can enhance the domestic R\&D innovation ability, improve the supply quality of domestic producer service factor, and then promote the development of servitization.

Based on the above analysis, this paper summarizes the impact mechanism of producer services openness on the development of servitization as shown in Figure 1. It can be seen from Figure 1 that the producer services openness not only improves the supply quality and enriches the supply types of producer service factor but also promotes the rapid development of domestic producer services through industrial connection effect, market competition effect, technology transfer and diffusion, technology reverse spillover, and other channels and effectively improves the supply environment of domestic producer service factor, and it provides important support for the development of servitization so as to accelerate the development of servitization.

According to the above explanation on the impact mechanism of producer services openness on the development of servitization, this paper puts forward Hypothesis 1.

H1. The producer services openness helps to promote the development of servitization.

In addition, due to the existence of sector heterogeneity, it is necessary to bring sector heterogeneity into the scope of research when investigating the impact of producer services openness on the development of servitization. Firstly, there are differences in openness, development level, factor input intensity, knowledge, and technology carried by different producer service sectors. Therefore, the impact of different producer service sector openness on the development of servitization may be different. At the same time, when Li et al. [13] investigated the impact of producer services openness on manufacturing productivity, they also found that the impact of producer service sector openness on manufacturing productivity is different. Based on this, in order to further investigate the heterogeneity impact of the producer service sector openness on the development of servitization, this paper puts forward Hypothesis 2.

H2. There is different impact of producer service sector openness on the development of servitization.

Secondly, according to the intensity of input factors, manufacturing industry is usually divided into labor intensive, capital intensive, and technology intensive. Zou et al. [3] pointed out that labor intensive manufacturing industry is dominated by labor input, so it is less sensitive to the change of intermediate producer service input. However, due to the high intensity of capital and technology input, capital intensive and technology intensive manufacturing industries are more dependent on capital and technology and need to embed more intermediate producer service factor in the production process, so it is sensitive to the change of intermediate productive service input. Therefore, the impact of producer services openness on the development of servitization with different factor intensities may be different. Based on this, this paper puts forward Hypothesis 3.

H3. The impact of producer services openness on the development of servitization with different factor intensities is also different.

Finally, the demand for the input of intermediate producer service factor in different factor intensive manufacturing industry sector is different. For example, the demand for financial service and professional service in capital intensive manufacturing industry is usually higher than that of labor intensive. Obviously, there may be differences in the impact of different producer service sector openness on different factor intensive servitization. Therefore, this paper further puts forward Hypothesis 4 .

H4. There is also different impact of producer service sector openness on the development of servitization with different factor intensities.

\section{Research Design}

3.1. Empirical Model. In order to analyze the impact of the producer services openness on the development of servitization, the following empirical benchmark model is established based on the research of Huang and Huo [26], Dai [27], and Zou et al. [3]:

$$
\mathrm{ms}_{i t}=\alpha+\Gamma s s t_{i t}+\Theta X_{i t}+\mu_{i}+v_{t}+\varepsilon_{i t} .
$$

Among them, $i$ denotes the industry, $t$ denotes the year, $\mathrm{ms}_{i t}$ denotes the development of servitization, $s t_{i t}$ denotes the openness of producer services, $X_{i t}$ are the control variables, including R\&D activities, development of producer services, competitiveness, and profitability of manufacturing industry, $u_{i}$ is the industry effect, $v_{t}$ is the time effect, and $\varepsilon_{i t}$ is the random error term. 


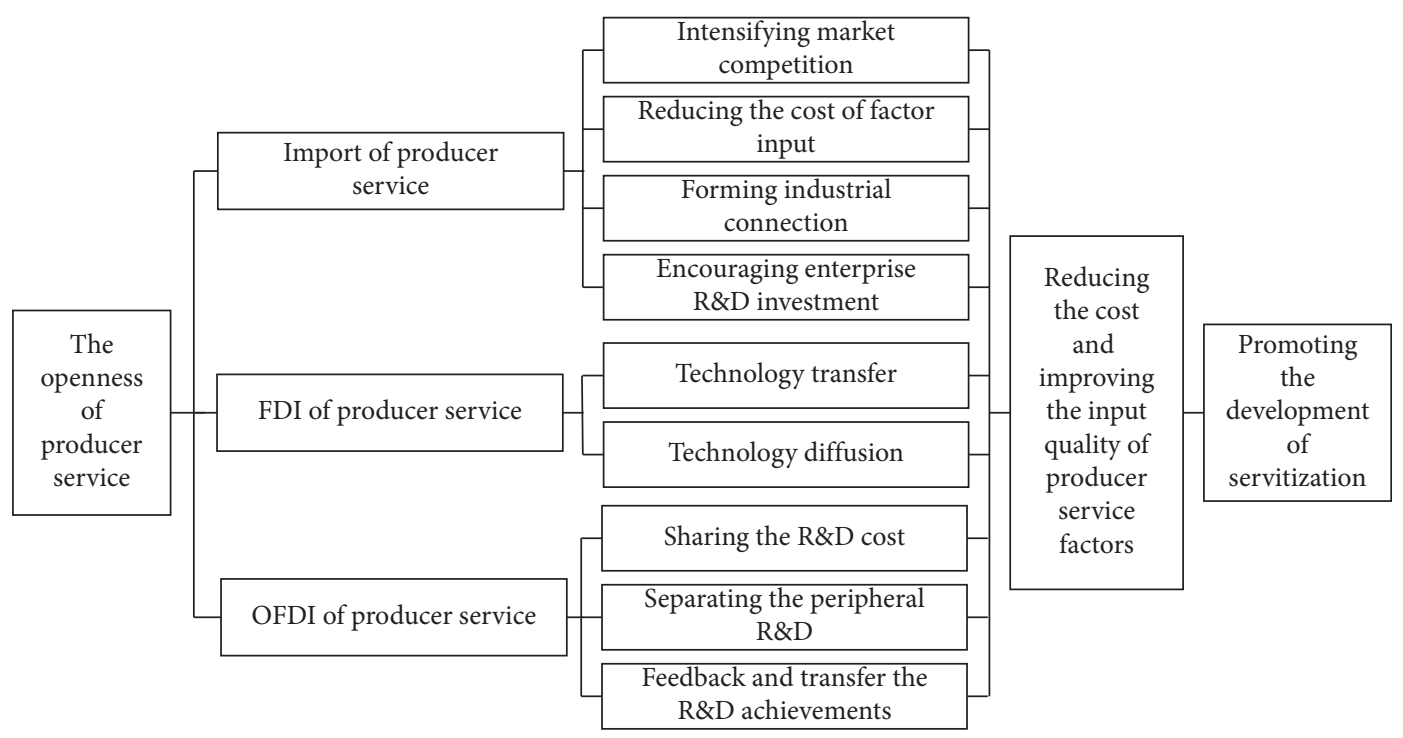

FIGURE 1: The impact mechanism of producer services openness on the development of servitization.

\subsection{Variable Description and Measurement}

3.2.1. Servitization. Servitization refers to the transformation of value chain from manufacturing to service. It is generally measured by the proportion of service input or output. In this paper, the methods of Liu et al. [28], Lv et al. [29], and Geng and Wang [30] are used to measure the development of servitization by using the proportion of service input. In particular, direct or complete consumption coefficient can be used to measure the development of servitization. The direct consumption coefficient reflects the direct consumption degree of the total output of a manufacturing industry to each service sector, which can be expressed as follows:

$$
a_{i j}=\frac{q_{i j}}{Q_{j}} .
$$

Among them, $a_{i j}$ denotes the direct consumption coefficient of manufacturing sector $j$ to service sector $I$ and $q_{i j}$ indicates the production output of manufacturing sector $j$ that need to consume the service quantity of service sector $i$. In the production process, in addition to direct consumption, there is also indirect consumption. The total direct and indirect consumption of manufacturing sector to service sector constitutes the complete consumption, and it can be expressed as follows:

$$
b_{i j}=a_{i j}+\sum_{k=1}^{n} a_{i k} a_{k j}+\sum_{k=1}^{n} \sum_{s=1}^{n} a_{i s} a_{i k} a_{k j}+\cdots .
$$

Among them, the first item is the direct consumption coefficient of manufacturing sector $j$ to service sector $i$, the second item is the first round indirect consumption coefficient of manufacturing sector $j$ to service sector $i$ through manufacturing sector $k$, and so on. Thus, the complete consumption coefficient can more accurately measure the development of servitization. Therefore, the complete consumption coefficient is used to express the development of servitization in this paper.
3.2.2. Producer Servicesopenness. As for the measurement of service industry openness, scholars usually use such indicators as service trade volume [31], service Industry FDI [32], service Industry FDI and service trade volume [33], and service industry liberalization index [34]. Under the new pattern of expanding openness, the openness of producer services contains two levels of meaning: "bringing in" and "going out." Therefore, based on the service industry openness measurement of relevant research results, this paper measures the producer services openness from the perspective of two-way openness.

How to describe the relationship between the openness of producer services and the development of servitization is the key to this paper. Based on the research ideas of Arnold et al. [35] and Zhang et al. [7], this paper uses the inputoutput table to calculate the penetration rate of producer services openness to the manufacturing industry from the perspective of producer service input and then use it to measure the impact of producer services openness on the development of servitization. The specific measurement is as follows:

$$
\text { sst }_{i t}=\sum_{k} \delta_{i k t} \text { service_open }_{k t} .
$$

Among them, $\delta_{i k t}$ is the input proportion of the service industry calculated by using the input-output table data, $i$ is the manufacturing sector, $k$ is the producer service sector, $t$ is the year; $s s t_{i t}$ is the penetration rate of producer services openness to the manufacturing sector; and service_open ${ }_{k t}$ is the index of producer services openness. Based on the research of Chen and Wei [14] and Zou et al. [3], this paper selects the import, FDI, and OFDI of producer services as the measurement indicators and uses formula (4) to calculate the penetration rate of each opening index to manufacturing industry and obtains the import penetration rate, FDI penetration rate, and OFDI penetration rate of producer services. 
3.2.3. Control Variables. On the basis of the existing research results, the main control variables of this paper are as follows:

(1) R\&D Activities ( $r d$ ). Continuous $R \& D$ investment is an important guarantee to improve the innovation ability of manufacturing industry. At the same time, the stronger the innovation ability of manufacturing industry, the richer the types of knowledge resources and the lower cost of acquiring specific knowledge resources, which plays an important role in promoting the development of servitization [26]. In this paper, R\&D investment intensity is used to represent R\&D activities of manufacturing industry, and the $R \& D$ intensity is measured by the ratio of $R \& D$ expenditure and main business income of each manufacturing sector, referring to the practice of Huang and Huo [26] and Dai [27].

(2) Development of Producer Services (cyjg). The development of producer services determines the quality and type of intermediate producer service factor input in domestic manufacturing industry.

The higher the development of producer services, the richer the types and the higher the quality of intermediate producer service, and it not only effectively meets the diversified demand of manufacturing industry for producer service factors but also enables manufacturing industry to obtain low-cost and high-quality producer service factors, increases the input of them, and then promotes the development of servitization. The proportion of the output value of producer service in the output value of the tertiary industry is used to express the development of producer services in this paper.

(3) Competitiveness of Manufacturing Industry (jzl). The position of value chain has an important influence on the development of servitization [36]. The competitiveness of manufacturing industry is an important indicator to measure the development of manufacturing industry. The higher the position of manufacturing industry in the value chain indicates the stronger competitiveness. The stronger competitiveness means that manufacturing industry has stronger market control and resource organization ability so that it can overcome the challenges of market, production, and design in the process of servitization. Therefore, manufacturing enterprises with strong competitiveness are more able to promote service-oriented strategy [26]. The competitiveness of manufacturing industry is mainly reflected in the international market. Therefore, it is expressed by the proportion of the export volume of manufacturing industry in the total output of manufacturing industry.

(4) Profitability of Manufacturing Industry (yll). The empirical study found that the successful servitization transformation of manufacturing enterprises has strong profitability [37]. Therefore, it can be considered that the stronger the profitability of manufacturing enterprises, the more capable they are to promote the development of servitization. Although ROE is the core index to measure profitability, it is difficult to obtain the data of manufacturing industry's net profit. For this reason, referring to the research of Huang and Huo [26], this paper adopts the value-added rate of manufacturing industry instead and expresses it by the ratio of current price added value to total output.

3.2.4. Data Sources and Industry Definition. As the latest input-output table of China provided by the world inputoutput database (WIOD) in 2016, the deadline of inputoutput data is 2014, and considering the consistency of statistical caliber of other relevant data indicators, the selection interval of data is determined as 2000-2014. The related data and their sources are as follows.

(1) Explained Variable. The measurement data of the development of servitization come from WIOD's China input-output table. (2) Core explanatory variables. The FDI data of producer service sector come from China Statistical Yearbook from 2001 to 2015. By using the perpetual inventory method and referring to the research of Chen et al. [38], taking the depreciation rate as $5 \%$ to calculate the FDI stock data of producer service sector, the data of OFDI stock in producer service sector are from the statistical bulletin of China's foreign direct investment from 2000 to 2014. The import volume of producer service sector comes from the balance of payments from 2000 to 2014. (3) Control Variables. The measurement data of $\mathrm{R} \& \mathrm{D}$ investment intensity come from China Science and Technology Statistical Yearbook from 2001 to 2015. The measurement data of the development of producer services come from China Statistical Yearbook from 2001 to 2015. The measurement data of manufacturing competitiveness and profitability come from WIOD's China input-output Table. The descriptive statistics of variables is shown in Table 1.

As the division of manufacturing industry in China Statistical Yearbook is not completely consistent with WIOD's China input-output table, in order to seek the unity, this paper takes WIOD's China input-output table as the standard. Referring to the treatment method of Diao and Zhu [18], the division of manufacturing industry in China Statistical Yearbook is merged, and finally 13 manufacturing sectors are obtained, as shown in Table 2. With regard to the selection of producer service sector, this paper selects four sectors, such as transportation service, communication service, financial service, and professional service, based on the consistency of the division of producer service sector in balance of payments, China Statistical Yearbook, statistical bulletin of China's foreign direct investment, and WIOD's China input-output table. 
TABLE 1: The descriptive statistics of variables.

\begin{tabular}{lcccccc}
\hline Variables & Number & Average & Median & Standard deviation & Skewness & Kurtosis \\
\hline$m s_{i t}$ & 195 & 0.266 & 0.237 & 0.114 & 1.115 & -0.191 \\
ln jkst & 195 & 8.660 & 8.745 & 12.079 & 0.523 & 0.765 \\
ln fdist & 195 & 12.200 & 12.316 & 1.254 & -0.009 \\
ln ofdist & 195 & 12.379 & 1.373 & 0.363 & 0.096 \\
Rd & 195 & 1.452 & 42.901 & 2.217 & 0.622 \\
Cyjg & 195 & 43.241 & 6.667 & 10.890 & 1.951 \\
Jzl & 195 & 11.410 & 22.662 & 5.045 & 2.734 \\
Yll & 195 & 23.091 & & 5.036 & 0.836 \\
\hline
\end{tabular}

TABLE 2: Manufacturing sector.

\begin{tabular}{|c|c|c|}
\hline Number & Description & Code \\
\hline 1 & Manufacture of food products, beverages, and tobacco products & $\begin{array}{c}\mathrm{C} 10- \\
12\end{array}$ \\
\hline 2 & Manufacture of textiles, wearing apparel, and leather products & $\begin{array}{c}\mathrm{C} 13- \\
15\end{array}$ \\
\hline 3 & $\begin{array}{c}\text { Manufacture of wood and of products of wood and cork, except furniture; manufacture of articles of straw and plaiting } \\
\text { materials }\end{array}$ & $\mathrm{C} 16$ \\
\hline 4 & Manufacture of paper and paper products & $\mathrm{C} 17$ \\
\hline 5 & Printing and reproduction of recorded media & $\mathrm{C} 18$ \\
\hline 6 & Manufacture of coke and refined petroleum products & $\mathrm{C} 19$ \\
\hline 7 & Manufacture of chemicals and chemical products & $\mathrm{C} 20$ \\
\hline 8 & Manufacture of rubber and plastic products & $\mathrm{C} 22$ \\
\hline 9 & Manufacture of other nonmetallic mineral products & $\mathrm{C} 23$ \\
\hline 10 & Manufacture of basic metals & $\mathrm{C} 24$ \\
\hline 11 & Manufacture of computer, electronic and optical products, and electrical equipment & $\begin{array}{c}\mathrm{C} 26- \\
27\end{array}$ \\
\hline 12 & Manufacture of machinery and equipment $n$. e. $c$. & $\mathrm{C} 28$ \\
\hline 13 & Manufacture of motor vehicles, trailers and semitrailers, and other transport equipment & $\begin{array}{c}\mathrm{C} 29- \\
30\end{array}$ \\
\hline
\end{tabular}

\section{Empirical Analysis}

4.1. Benchmark Regression Analysis. In order to reduce the heterogeneity and considering that the impact of producer services openness on the development of servitization may be nonlinear, we take logarithm as the core explanatory variables. The estimated results of the benchmark regression are shown in Table 3. According to Table 3, the influences of import, FDI, and OFDI penetration of producer services on the development of servitization all pass the $1 \%$ significance level test, and the estimated values of each regression parameter are positive, which is basically consistent with the $\mathrm{H} 1$. From the regression results of control variables, the impact of manufacturing industry profitability is not significant. The reasons may be the rising of labor cost, the change of consumer consumption concept, and the increasing competition in international market, which makes the development of China's manufacturing industry under severe pressure. In order to actively respond to the survival challenges brought by the change of development environment, China's manufacturing industry carries out passive transformation through the implementation of servitization strategy. Therefore, the implementation of servitization strategy is more based on the passive transformation based on the survival consideration, rather than the active transformation based on the profitability. In addition, other control variables have a significant impact on the development of servitization.

\subsection{Sector Heterogeneity Analysis}

4.2.1. Producer Service Sector Openness. Considering the heterogeneity of the impact of the openness of producer services on the development of servitization, this part will further analyze the impact of producer services openness on the development of servitization from the perspective of sector openness. The estimated results are shown in Table 4. According to Table 4, the openness of transportation service sector and professional service sector has a significant impact on the development of servitization. By comparison, the development of China's transportation service sector still lags behind that of developed countries. The openness of transportation service sector can accelerate and promote its development to a more professional direction. With more specialized transportation service factor input, manufacturing industry can effectively reduce production costs, which has a positive effect on the development of servitization. In addition, the professional service market is very important for the development of servitization. The competitive effect and spillover effect brought by the openness of professional service sector can promote the 
TABLE 3: Benchmark regression results.

\begin{tabular}{lcccc}
\hline Variables & Model 1 & Model 2 & Model 3 & Model 4 \\
\hline ln jkst & $0.050^{* * *}(0.013)$ & & & $0.029^{* * *}(0.009)$ \\
ln fdist & & $0.246^{* * *}(0.013)$ & $0.227^{* * *}(0.012)$ \\
ln ofdist & & & $0.149^{* * *}(0.016)$ & $0.051^{* * *}(0.014)$ \\
Rd & $0.172^{* * *}(0.057)$ & $0.085^{* * *}(0.023)$ & $0.430^{* * *}(0.055)$ & $0.327^{* * *}(0.032)$ \\
Cyjg & $0.015^{* * *}(0.005)$ & $0.024^{* * *}(0.003)$ & $0.002(0.004)$ & $0.020^{* * *}(0.003)$ \\
Jzl & $0.002^{*}(0.001)$ & $0.005^{* * *}(0.001)$ & $0.002^{*}(0.001)$ & $0.003^{* * *}(0.001)$ \\
Yll & $0.001(0.002)$ & $0.001(0.002)$ & $0.001(0.002)$ & $0.001(0.002)$ \\
Cons & $-0.549^{* *}(0.238)$ & $-1.661^{* * *}(0.144)$ & $-0.938^{* * *}(0.189)$ & $-1.164^{* * *}(0.138)$ \\
Observation & 195 & 195 & 195 & 195 \\
Id & 13 & 13 & 13 & 13 \\
Hausman & 2.83 & $28.70^{* * *}$ & $30.68^{* * *}$ & 5.03 \\
Wald chi2/F & $42.98^{* * *}$ & $83.32^{* * *}$ & $24.42^{* * *}$ & $82.28^{* * *}$ \\
\hline
\end{tabular}

Note. ${ }^{* * *},{ }^{* *}$, and ${ }^{*}$, respectively, represent statistical significance at the level of $1 \%, 5 \%$, and $10 \%$, and the values in brackets are robust standard errors.

TABLE 4: Estimation results of producer service sector openness.

\begin{tabular}{lcccc}
\hline Variables & Transportation service & Communication service & Financial service & Professional service \\
\hline ln $j k s t$ & $0.020^{* *}(0.009)$ & $0.012(0.012)$ & $-0.002(0.010)$ & $0.019^{* * *}(0.006)$ \\
ln fdist & $0.208^{* * *}(0.024)$ & $0.103^{* * *}(0.030)$ & $0.028(0.019)$ & $0.108^{* * *}(0.023)$ \\
ln ofdist & $0.097^{* * *}(0.018)$ & $-0.002(0.013)$ & $0.011(0.010)$ & $0.052^{* * *}(0.013)$ \\
Rd & $0.093^{* *}(0.046)$ & $0.273^{* * *}(0.061)$ & $0.129^{* *}(0.054)$ & $0.146^{* * *}(0.068)$ \\
Cyjg & $0.010(0.006)$ & $0.017^{* *}(0.007)$ & $0.002(0.006)$ & $0.015^{* * *}(0.006)$ \\
Jzl & $0.004^{* * *}(0.001)$ & $0.002^{* * *}(0.001)$ & $0.004^{* * *}(0.001)$ & $0.003^{* * *}(0.001)$ \\
Yll & $0.001(0.002)$ & $0.001(0.002)$ & $0.002(0.002)$ & $0.004^{* *}(0.002)$ \\
Cons & $-1.875^{* *}(0.272)$ & $-0.996^{* * *}(0.342)$ & $-0.027(0.215)$ & $-0.123(0.238)$ \\
Observation & 195 & 195 & 195 & 195 \\
Id & 13 & 13 & 6.23 & 13 \\
Hausman & 3.72 & 2.42 & $52.60^{* * *}$ & $24.12^{* * *}$ \\
Wald chi2/F & $162.12^{* * *}$ & $179.33^{* * *}$ & $103.76^{* * *}$ \\
\hline
\end{tabular}

Note. ${ }^{* *},{ }^{* *}$, and ${ }^{*}$, respectively, represent statistical significance at the level of $1 \%, 5 \%$, and $10 \%$, and the values in brackets are robust standard errors.

development of China's professional service market so as to better meet the demand of the development of servitization for professional service factor.

The openness of communication service sector only affects the development of servitization through the channel of FDI penetration. Due to the monopoly of the communication service market, most China's communication services are provided by state-owned or state-owned holding enterprises, and the market competition is still insufficient. In order to promote the development of China's servitization, under the new pattern of expanding openness, China should gradually reduce the access threshold and increase the investment attraction of communication service sector. By improving the competition degree of communication services market, we can provide high-quality and low-cost communication services for the development of servitization.

The openness of financial service sector has no significant impact on the development of servitization, and the possible reasons are as follows. Firstly, during the process of servitization, the focus of production and operation has gradually shifted from heavy asset investment to light asset one, resulting in a significant reduction in the demand for financing. Secondly, the implementation of servitization strategy is usually the manufacturing enterprises with rich fund, whose financing reputation is high, and often forms a close interdependence with domestic financial service providers. Thirdly, although the openness of financial service sector can provide more abundant financial service products for the market, due to the imperfect interest rate liberalization in China, the impact of financial service sector openness on the financial service market is relatively limited, and it has not effectively reduced the input cost of financial service factor for manufacturing enterprises.

The empirical test results show that the impact of different producer services openness on the development of servitization is different, which also verifies the $\mathrm{H} 2$.

4.2.2. Manufacturing Sector. In order to investigate whether the openness of producer services has a heterogeneous impact on the development of servitization with different factor intensities, here, referring to the division method of Dai [27] and Diao and Zhu [18], 13 manufacturing industries are divided into labor intensive, capital intensive, and technology intensive according to the factor intensity. The estimated results of the impact of producer services openness on the development of servitization with different factor intensities are shown in Table 5. Table 5 shows the following. Firstly, for labor intensive manufacturing sector, 
TABLE 5: Estimated results of manufacturing sector.

\begin{tabular}{lccc}
\hline Variables & Labor intensive & Capital intensive & Technology intensive \\
\hline $\ln j$ jst & $0.021^{* *}(0.009)$ & $0.013^{* * *}(0.005)$ & $0.017(0.012)$ \\
$\ln$ fdist & $0.042^{* * *}(0.011)$ & $0.112^{* * *}(0.012)$ & $0.290^{* * *}(0.030)$ \\
ln ofdist & $0.001(0.010)$ & $0.033^{* * *}(0.011)$ & $0.047^{* * *}(0.021)$ \\
Rd & $0.008(0.025)$ & $0.185^{* * *}(0.028)$ & $0.383^{* * *}(0.072)$ \\
Cyjg & $0.003(0.002)$ & $0.007^{* *}(0.003)$ & $0.028^{* * *}(0.007)$ \\
Jzl & $0.004^{* * *}(0)$ & $0.003^{* * *}(0.001)$ & $0.002(0)$ \\
Yll & $-0.006^{* * *}(0.001)$ & $0(0)$ & $0(0)$ \\
Cons & $-0.023(0.128)$ & $1.084^{* * *}(0.127)$ & $-2.446^{* * *}(0.315)$ \\
Observation & 60 & 75 & 60 \\
Id & 4 & 5 & 4 \\
Hausman & $88.68^{* * *}$ & 4.63 & 3.72 \\
Wald chi2/F & $35.17^{* * *}$ & 252.17 & 92.74 \\
\hline
\end{tabular}

Note. ${ }^{* * *},{ }^{* *}$, and ${ }^{*}$, respectively, represent statistical significance at the level of $1 \%, 5 \%$, and $10 \%$, and the values in brackets are robust standard errors.

the openness of producer services affects the development of labor intensive servitization through import and FDI penetration channels, while the influence of OFDI penetration channel is not significant. The production process of labor intensive manufacturing sector relies more on the input of labor factors. However, in order to implement the servitization strategy, the proportion of intermediate input producer service factors must be increased, which leads to the substantial increase in the demand for intermediate produce service factors. The import and FDI of producer service can effectively improve the supply environment of them, which can better meet the demand of labor intensive manufacturing industry and then promote the development of labor intensive servitization. However, OFDI of producer services mainly affects the domestic producer service supply market through reverse technology spillover channels, and its impact is mainly concentrated on highend producer service, such as professional service, financial service, and so on. The demand of labor intensive manufacturing sector is mainly concentrated in low-end producer service, while the demand for high-end producer service is relatively limited. This may be the main reason why OFDI penetration has no significant impact on the development of labor intensive servitization. Secondly, for the capital intensive and technology intensive manufacturing sector, the impact of import penetration on the development of technology intensive servitization is not significant, but the impact on the development of capital intensive servitization is significant, while FDI and OFDI penetration have significant impact on the development of capital and technology intensive servitization. Capital and technology intensive manufacturing sectors are highly dependent on capital and technology. The introduction of high-end producer service providers and the reverse technology spillover effect of OFDI in producer services can improve the supply environment of China's high-end producer service factor and help to reduce its cost and optimize the input structure so as to promote the development of capital and technology intensive servitization.

Therefore, it can be concluded that the impact of producer services openness on servitization with different factor intensities is different, which verifies the H3.
4.2.3. Producer Service Sector Openness and Manufacturing Sector. Based on the above research, this part further examines the impact of different producer service sector openness on the development of servitization with different factor intensities. The estimated results are shown in Table 6 . It can be concluded from Table 6 that, firstly, from the perspective of transportation service sector openness, the openness of transportation service sector has a significant impact on the development of labor and capital intensive servitization, but the openness of transportation service sector only affects the development of technology intensive servitization through OFDI penetration channel; secondly, from the perspective of communication service sector openness, FDI penetration is the only channel for the openness of communication service to affect the development of labor and capital intensive servitization, but the openness of communication service promotes the development of technology intensive servitization through FDI and OFDI penetration channels; then, from the perspective of financial service sector openness, the impact of financial service sector openness on the development of labor and technology intensive servitization is not significant. Financial service sector openness affects the development of capital intensive servitization through FDI penetration channel; finally, from the perspective of professional service sector openness, professional service sector openness has a significant impact on the development of capital intensive servitization. The FDI penetration of professional service has no significant impact on the development of capital intensive servitization, but it has a significant impact on the development of labor intensive servitization.

Therefore, it can be concluded that the impact of producer service sector openness on the development of servitization with different factor intensities is also different. This conclusion also verifies the $\mathrm{H} 4$.

4.3. Robustness Analysis. In order to ensure the reliability of the above research conclusions, this part will analyze the robustness of the above empirical research conclusions through different measures of variable and different parameter estimation methods. 
TABLE 6: Estimated results of producer service sector openness and manufacturing sector.

\begin{tabular}{|c|c|c|c|c|c|}
\hline Manufacturing sector & Variables & Transportation service & Communication service & Financial service & Professional service \\
\hline \multirow{5}{*}{ Labor intensive } & $\ln j k s t$ & $0.018^{* *}(0.008)$ & $0.013(0.010)$ & $0.010(0.007)$ & $0.010(0.007)$ \\
\hline & $\ln$ fdist & $0.058^{* * *}(0.013)$ & $0.037^{* *}(0.015)$ & $0.015(0.012)$ & $0.057^{* * *}(0.019)$ \\
\hline & $\ln$ ofdist & $0.009^{* * *}(0.004)$ & $0.001(0.003)$ & $0.009(0.005)$ & $0.006(0.005)$ \\
\hline & Hausman & $121.77^{* * *}$ & $41.94^{* * *}$ & $169.22^{* * *}$ & $86.23^{* * *}$ \\
\hline & Wald chi $2 / \mathrm{F}$ & $36.56^{* * *}$ & $21.99^{* * *}$ & $30.46^{* * *}$ & $23.90^{* * *}$ \\
\hline \multirow{5}{*}{ Capital intensive } & jkst & $0.017^{* * *}(0.005)$ & $0.014(0.011)$ & $0.007(0.006)$ & $0.029^{* * *}(0.009)$ \\
\hline & fdist & $0.125^{* * *}(0.014)$ & $0.074 * * *(0.014)$ & $0.078^{* * *}(0.013)$ & $0.010(0.036)$ \\
\hline & ofdist & $0.008^{* * *}(0.003)$ & $0.005(0.008)$ & $0.012(0.010)$ & $0.021^{* *}(0.010)$ \\
\hline & Hausman & 3.66 & 4.52 & 4.32 & 6.74 \\
\hline & Wald chi $2 / \mathrm{F}$ & $205.37^{* * *}$ & $64.27^{* * *}$ & $102.66^{* * *}$ & $32.17^{* * *}$ \\
\hline \multirow{5}{*}{ Technology intensive } & jkst & $0.023(0.024)$ & $0.086^{* * *}(0.022)$ & $-0.002(0.017)$ & $0.133^{* * *}(0.023)$ \\
\hline & ofdist & $0.316^{* * *}(0.030)$ & $0.386^{* * *}(0.045)$ & $0.016(0.022)$ & $0.396^{* * *}(0.025)$ \\
\hline & ofdis & $0.055(0.036)$ & $0.012(0.019)$ & $0.034(0.024)$ & $0.012^{* *}(0.007)$ \\
\hline & Hausman & 6.84 & 2.67 & 5.43 & 6.08 \\
\hline & Wald chi $2 / \mathrm{F}$ & $144.86^{* * *}$ & $300.85^{* * *}$ & $192.66^{* * *}$ & $201.63^{* * *}$ \\
\hline
\end{tabular}

Note. ${ }^{* * *},{ }^{* *}$, and ${ }^{*}$, respectively, represent statistical significance at the level of $1 \%, 5 \%$, and $10 \%$, and the values in brackets are robust standard errors.

TABLE 7: Variable robustness analysis.

\begin{tabular}{lccr}
\hline Variable & Model 5 & Model 6 & Model 7 \\
\hline ln jkst & $0.004^{* * *}(0.001)$ & $0.004^{* *}(0.002)$ & $0.057^{* * *}(0.012)$ \\
ln fdist & $0.017^{* * *}(0.004)$ & $0.012^{* * *}(0.003)$ & $0.129^{* * *}(0.020)$ \\
ln ofdist & $0.005^{* * *}(0.002)$ & $0.006^{* * *}(0.002)$ & $0.012^{* * *}(0.005)$ \\
Rd & $0.022^{* *}(0.009)$ & $0.040^{* * *}(0.009)$ & $0.383^{* * *}(0.056)$ \\
Cyjg & $0.001^{* * *}(0)$ & $0.004^{* * *}(0.001)$ & $0.017^{* * *}(0.006)$ \\
Jzl & $0.001^{* * *}(0)$ & $0.001^{* * *}(0)$ & $0.004^{* * *}(0.001)$ \\
Yll & $0(0)$ & $0(0)$ & $0.003^{*}(0.002)$ \\
Cons & $-0.152^{* * *}(0.041)$ & $-0.151^{* * *}(0.042)$ & $-1.718^{* * *}(0.285)$ \\
Observation & 195 & 195 & 195 \\
Id & 13 & 13 & 13 \\
Hausman & 2.47 & 3.92 & 5.21 \\
Wald chi2/F & $83.27^{* * *}$ & $81.72^{* * *}$ & $185.08^{* * *}$ \\
\hline
\end{tabular}

Note. ${ }^{* * *},{ }^{* *}$, and ${ }^{*}$, respectively, represent statistical significance at the level of $1 \%, 5 \%$, and $10 \%$, and the values in brackets are robust standard errors.

4.3.1. Variable Robustness Analysis. Generally, we can use flow and stock to measure the change characteristics of producer services FDI and OFDI. The stock index mainly reflects the change characteristics of a certain time point, and the flow index mainly reflects the change characteristics of a certain period. In this paper, the empirical results are verified by using the flow data of FDI and OFDI in producer services. At the same time, the direct consumption coefficient represents the one-time consumption of intermediate service factors input by manufacturing industry, which is usually used to measure the development of servitization. Therefore, when the robustness analysis of variable is carried out, the situation of replacing the complete consumption coefficient with direct consumption coefficient is considered. The results of the robustness analysis are shown in Table 7. The explained variable of model 5 and model 6 is measured by direct consumption coefficient, while the explained variable of model 7 is measured by complete consumption coefficient, and the FDI and OFDI penetration rate of producer services in model 5 and model 7 are calculated by the stock index, and the FDI and OFDI penetration rate of producer services in model 6 and model 7 are calculated by the flow index. The results of Table 7 show that although the measures of explained variables and explanatory variables are replaced, respectively, the significance level and sign of core variable estimation parameters are basically consistent with those in Table 3.

\subsubsection{Endogenous Elimination Robustness Analysis.} Different estimation methods may affect the estimation results of model parameters. In this paper, OLS, 2SLS, and SYS-GMM methods are used to estimate the parameters of the benchmark model. In fact, the OLS method is used to estimate the parameters of the benchmark model as a mixed data model, while 2SLS and SYS-GMM methods are mainly used to solve or alleviate the endogenous problems that may exist in the model. The estimated results are shown in Table 8. Although there are certain differences in parameter estimation values and significance levels under different estimation methods, the conclusions are basically consistent with those obtained by benchmark regression. 
TABLE 8: Estimation methods robustness analysis.

\begin{tabular}{lccr}
\hline Variable & OLS & 2SLS & SYS-GMM \\
\hline $\ln j k s t$ & $0.020^{* * *}(0.005)$ & $0.031^{*}(0.017)$ & $0.005^{* *}(0.003)$ \\
$\ln$ fdist & $0.237^{* * *}(0.015)$ & $0.175^{* * *}(0.032)$ & $0.276^{* * *}(0.012)$ \\
ln ofdist & $0.067^{* * *}(0.013)$ & $0.003^{* * *}(0.001)$ & $0.045^{* * *}(0.015)$ \\
Rd & $0.358^{* * *}(0.034)$ & $0.165^{* * *}(0.046)$ & $0.256^{* * *}(0.030)$ \\
Cyjg & $0.023^{* * *}(0.007)$ & $0.011^{* * *}(0.005)$ & $0.029^{* * *}(0.003)$ \\
Jzl & $0.003^{* * *}(0)$ & $0.004^{* * *}(0.001)$ & $0.005^{* * *}(0.001)$ \\
Yll & $0.001(0.001)$ & $0(0)$ & $0.002(0.002)$ \\
Cons & $-2.163^{* * *}(0.122)$ & $-1.446^{* * *}(0.328)$ & $-2.152^{* * *}(0.124)$ \\
Sargan & & & $208.349^{* * *}$ \\
$R^{2}$ & 0.924 & 0.872 & $535.66^{* * *}$ \\
Wald chi2/F & $235.11^{* * *}$ & $192.02^{* * *}$ & 5 \\
\hline
\end{tabular}

Note. ${ }^{* * *},{ }^{* *}$, and ${ }^{*}$, respectively, represent statistical significance at the level of $1 \%, 5 \%$, and $10 \%$, and the values in brackets are robust standard errors.

\section{Conclusions}

Under the new situation of expanding the openness of producer services, this paper brings the "bringing in" and "going out" of producer services into the same analysis framework. On the basis of discussing the impact mechanism of producer services openness on the development of servitization, this paper points out that producer services openness promotes the development of servitization through the three channels of producer services import, producer services FDI, and OFDI". Then, the paper empirically analyzes the impact of producer services openness on the development of servitization from both the overall and sector levels, and the specific conclusions are as follows.

Firstly, whether it is based on the import, FDI, or OFDI penetration rate, the openness of producer services can significantly promote the development of servitization. The research conclusion is robust through the robustness analysis of variable and parameter estimation method.

Secondly, the impact of producer service sector openness on the development of servitization has heterogeneity.

There is different impact of producer service sector openness on the development of servitization. In addition to financial service sector, the openness of transportation service sector, communication service sector, and professional service sector has a significant positive impact on the development of servitization, but the openness of communication service sector only affects the development of servitization through FDI penetration channel.

The impact of producer services openness on the development of servitization with different factor intensities is also different. FDI penetration has a significant impact on the development of different factor intensive servitization, while import penetration only has a significant impact on the development of labor and capital intensive servitization and OFDI penetration has a significant impact on the development of both capital and technology intensive servitization.

The impact of producer service sector openness on the development of servitization with different factor intensities is also different. The openness of transportation service sector has a significant impact on the development of labor and capital intensive servitization, but the openness of transportation service sector only affects the development of technology intensive servitization through FDI penetration channel. The openness of communication service affects the development of technology intensive servitization through import and FDI penetration channels and improves the development of labor and capital intensive servitization through FDI penetration channel. However, the OFDI penetration channel of communication service sector has no significant impact on the development of servitization with different factor intensities. The openness of financial service sector only affects the development of capital intensive servitization through FDI penetration channel, while the openness of financial service sector has no significant impact on the development of labor and technology intensive servitization. The openness of professional service sector has a significant impact on the development of technology intensive servitization, but the openness of professional service sector only affects the development of labor intensive servitization through FDI penetration channel and affects the development of capital intensive servitization through import and OFDI penetration channels.

The policy implications of these research conclusions are as follows: firstly, take co-construction of the "Belt and Road" as a chance to promote the new open pattern by paying equal attention to "bringing in" and "going out"; secondly, focus on expanding the openness of high-end producer services to build a new open pattern of opening up and optimize the input structure of producer services; and thirdly, taking innovation driven development as the guide, increase R\&D investment of producer services.

\section{Data Availability}

The data used to support the findings of this study are available from the corresponding author upon request.

\section{Conflicts of Interest}

The authors declare that they have no conflicts of interest.

\section{Acknowledgments}

The authors acknowledge funding from the National Social Science Foundation of China (Project no. 20BJY095), the Natural Science Foundation of Chongqing (Project no. 
cstc2020jcyj-msxmX0864), the Humanities and Social Sciences Foundation of Chongqing Education Commission (Project no. 19SKGH080), and the contributions from all partners of the mentioned projects.

\section{References}

[1] M. Y. Liu and M. J. Rui, "Research on constructing mode of China modern industry system under globalization conditions," China Industrial Economics, vol. 27, no. 5, pp. 57-66, 2009.

[2] L. Yang, "Imported producer services affects manufacturing servitization," The Journal of Quantitative \& Technical Economics, vol. 32, no. 5, pp. 37-53, 2015.

[3] G. W. Zou, X. Y. Ji, X. D. Hu, and P. P. Hu, "Does service trade opening promote the servitization of manufacturing industry?" Industrial Economics Research, vol. 17, no. 6, pp. 62-74, 2018.

[4] Y. H. Meng and X. S. Yin, "Trade in producer service and technology efficiency of China's manufacturing," World Economy Studies, vol. 29, no. 7, pp. 38-44, 2010.

[5] Q. F. Chen and Z. B. Liu, "Empirical analysis for the impact of import producer service on China's manufacturing industries total factor productivity," The Journal of Quantitative \& Technical Economics, vol. 31, no. 3, pp. 74-88, 2014.

[6] J. M. Arnold, B. S. Javorcik, and A. Mattoo, "Does services liberalization benefit manufacturing firms?" Journal of International Economics, vol. 85, no. 1, pp. 136-146, 2011.

[7] Y. Zhang, Y. H. Tang, and M. H. Zhou, "Does the liberalization of service trade improve the production efficiency of manufacturing enterprises," The Journal of World Economy, vol. 36, no. 11, pp. 51-71, 2013.

[8] O. Shepotylo and V. Vakhitov, "Services liberalization and productivity of manufacturing firms," The Economics of Transition, vol. 23, no. 1, pp. 1-44, 2015.

[9] A. M. Fernandes and C. Paunov, "Foreign direct investment in services and manufacturing productivity: evidence for Chile," Journal of Development Economics, vol. 97, no. 2, pp. 305-321, 2012.

[10] G. L. Gou and H. X. Lu, "Could FDI in producer services promote the total factor productivity of the manufacturing industry?" Journal of Capital University of Economics and Business, vol. 19, no. 5, pp. 44-52, 2017.

[11] J. H. Chen, "Firm heterogeneity, TFP and FDI in services: an empirical test based on data from service industries and firms," Journal of International Trade, vol. 40, no. 7 , pp. 112-122, 2014.

[12] J. H. Chen, "Industry heterogeneity, ownership advantages and FDI in services: empirical analysis based on panel data of service industries in China," World Economy Studies, vol. 34, no. 9, pp. 86-93, 2015.

[13] Y. Li, L. Yan, and T. X. Zhang, “The opening up of China's producer service industry and the promotion of total factor productivity in manufacturing industry: based on the study of industry heterogeneity," Journal of Zhejiang University, vol. 48, no. 4, pp. 94-110, 2018.

[14] M. Chen and Z. L. Wei, "Study on the opening of producer services and China's manufacturing productivity: an angle of subdivision industry in producer services," Economic Review, vol. 39, no. 3, pp. 59-73, 2018.

[15] M. Chen, Q. Wei, and M. Y. Kuang, "The impact of the opening of producer services on China's industrial productivity and its international comparison," Journal of
Guangdong University of Finance \&Economics, vol. 34, no. 1, pp. 4-13, 2019.

[16] M. Kugler and E. Verhoogen, "Prices, plant size, and product quality," The Review of Economic Studies, vol. 79, no. 1, pp. 307-339, 2012.

[17] H. Fan, X. Gao, Y. A. Li, and T. A. Luong, "Trade liberalization and markups: micro evidence from China," Journal of Comparative Economics, vol. 46, no. 1, pp. 103-130, 2018.

[18] L. Diao and Q. Zhu, "The impact of producer services import on China's service-oriented manufacturing," China Soft Science, vol. 33, no. 8, pp. 49-57, 2018.

[19] M. H. Shen and W. S. Liu, "The effect of service openness on resource misallocation of manufacture: evidence from the micro data," Journal of International Trade, vol. 42, no. 11, pp. 97-107, 2016.

[20] G. D. Gu and H. Q. Zhu, "The technical content of trade in service and industrial productivity: an empirical study based on multinational panel data," International Economics and Trade Research, vol. 33, no. 2, pp. 4-16, 2017.

[21] H. Shen and R. H. Gu, "Does service trade opening promote manufacturing productivity?" Research on Economics and Management, vol. 38, no. 3, pp. 72-81, 2017.

[22] Z. Q. Yao, "The impact of China's service industry opening on China's export technology complexity," Academic Forum, vol. 42, no. 1, pp. 79-87, 2019.

[23] W. Zhao, G. D. Gu, and Y. Q. He, "OFDI and China's technological progress: mechanism analysis and empirical study," Management World, vol. 32, no. 7, pp. 53-601, 2006.

[24] Y. Z. Chen, "Research on the reverse technology spillover of Taiwan's direct investment in service industry to mainland," Journal of Shandong University of Science and Technology, vol. 20 , no. 5, pp. 67-72, 2018.

[25] H. B. Sun and Z. L. Liu, "Does OFDI reverse technology spillover promote China's industrial green transformation: empirical evidence from provincial panel data in China," Journal of International Trade, vol. 45, no. 3, pp. 161-174, 2019.

[26] Q. H. Huang and J. D. Huo, "The servitization intensity of manufacturing and its influencing factors: based on the world input-output data analysis," Business Management Journal, vol. 36 , no. 1, pp. 1-11, 2014.

[27] X. Dai, "Evolution and determinants of service added value embodied in China's manufactured exports," Economic Research Journal, vol. 51, no. 9, pp. 44-57, 2016.

[28] B. Liu, Q. Wei, Y. Lv, and K. F. Zhu, "Servitization of manufacturing and value chain upgrading," Economic Research Journal, vol. 51, no. 3, pp. 151-162, 2016.

[29] Y. Lv, X. M. Li, and Y. L. Lv, "Servicification in global value chain and firm's productivity," Nankai Economic Studies, vol. 33, no. 3, pp. 88-110, 2017.

[30] W. Geng and H. Y. Wang, "Input servitization in manufacturing and expo markup: evidence from Chinese firms," Journal of International Trade, vol. 45, no. 4, pp. 92108, 2019.

[31] J. Francois and J. Woerz, "Producer services, manufacturing linkages, and trade," Journal of Industry, Competition and Trade, vol. 8, no. 3-4, pp. 199-229, 2008.

[32] S. Dolly, "Do the FDI inflows affect domestic investment?" Journal of Developing Areas, vol. 49, no. 6, pp. 173-190, 2015.

[33] M. Chen and Z. L. Wei, "The impact of China's service industry opening on the upgrading of industrial structure," Economist, vol. 28, no. 4, pp. 24-32, 2016.

[34] J. C. Xia and Z. Q. Yao, "40 years opening up of the service industry in China: gradual process, openness evaluation and 
experience summary," Research on Financial and Economic Issues, vol. 40, no. 4, pp. 3-14, 2018.

[35] J. M. Arnold, B. S. Javorick, M. Lipscomb, and A. Mattoo, "Services reform and manufacturing performance: evidence from India," Economic Journal, vol. 126, no. 2, pp. 1-39, 2016.

[36] G. Lay, G. Copani, A. Jäger, and S. Biege, "The relevance of service in European manufacturing industries," Journal of Service Management, vol. 21, no. 5, pp. 715-726, 2010.

[37] H. Gebauer and T. Friedli, "Behavioral implications of the transition process from products to services," Journal of Business \& Industrial Marketing, vol. 20, no. 2, pp. 70-78, 2005.

[38] Y. Z. Chen, Q. Y. Guo, and H. Y. Li, "Research on the biased technical progress of China's service industry and its internal logic," Journal of Yunnan University of Finance and Economics, vol. 35, no. 4, pp. 39-49, 2019. 